\title{
Walking Borders, Risk and Belonging
}

Maggie O'Neill ${ }^{1}$ and Ismail Einashe ${ }^{2}$

${ }^{1}$ University College Cork, Cork Ireland and ${ }^{2}$ Journalist and Cambridge University, Cambridge England

\begin{abstract}
Walking borders, risk \& belonging makes a case for using walking as a biographical interview method (WIBM) in order to do critical public pedagogy-using conjunctural analysis-that engages in unsettling and troubling the white, male privilege and basis of walking, and indeed the 'turn' to walking rooted in Eurocentric practices. The authors build upon a long history of: i) using walking, participatory and arts-based methods (ethno-mimesis) to do social research on migration with migrants, and; ii) the importance of creating space for stories of asylum, migration and marginalisation to be shared and heard through critical pedagogy, critical journalism, and walking as an arts-based research method.
\end{abstract}

\section{Keywords}

Walking borders; conjunctural analysis; walking interview biographical method (WIBM); artsbased research; migration. 
Walking borders, risk \& belonging makes a case for using walking as a biographical interview method (WIBM) in order to do critical public pedagogy that engages in unsettling and troubling the white, male privilege and basis of walking, and indeed the 'turn' to walking rooted in Eurocentric practices. The authors build upon a long history of: i) doing social research using walking, participatory and arts-based methods (ethno-mimesis) on migration with migrants, and; ii) the importance of creating space for stories of asylum, migration and marginalisation to be shared and heard through critical pedagogy, critical journalism and walking as an arts-based research method - towards a radical democratic imaginary.

In this paper, the authors share a walk they undertook together in London, their conversation along the way, and its connections to the landmarks, places and spaces of Ismail's biography; in doing so, they tell a story that activates walking as method, and 'decodes', 'interrupts' and challenges dominant ideologies of race, class, gender and neoliberalism through mobile, conjunctural analysis (Hall, 1987). The walk and accompanying images open a space for dialogue and a 'radical democratic imaginary', where embodied knowledge, experience and memories are shared, that both advances innovations in biographical, visual/performative methods and critical pedagogy and, importantly, cuts across the 'procedural ethics' that have emerged in recent years through sensory and mobile methods, and an ethics of listening, trust, respect and recognition.

The authors met at a conference in 2017, to which they had both been invited to speak about their respective research on migration: Maggie, from the perspective of a feminist academic researcher committed to participatory arts-based methods and the importance of critical cultural analysis and arts practice with asylum seekers and refugees, Ismail, from the perspective of a journalist who reports on the stories of displaced people at the borders of Europe. Although there are differences between us in terms of roles (journalist and academic) as well as age, race, gender and positionality, we have values, ideas and interests in common. We both work on migration and use inclusive, creative, participatory methods, while Maggie's family history of Irish migration is important for Ismail in that we have migration histories in common.

Maggie (like the rest of the conference) was moved by Ismail's presentation and invited him to collaborate on a walk as part of her Leverhulme research fellowship on Borders, Risk and Belonging. Ismail accepted, and suggested they take the walk in London through Kentish Town and Camden. Ismail wanted to go on the walk to reimagine how, through an academic lens, he could understand where he grew up, and hoped that the collaboration might enable both him and Maggie to reimagine the research subjects we both cover. Later still, Ismail would take part in a conference organised by the migration network at York University as the keynote speaker and inspire $\mathrm{PhD}$ students both substantively and methodologically.

The Leverhulme Fellowship, and walking as a biographical interview method, sought to consolidate a long history of using walking as a method for doing social research as well as to interrogate walking as a method for conducting research on borders, risk and belonging. The intention was to invite artists, researchers, activists and citizens to share a walk on borders, risk and belonging - to map or plan the walk, preferably draw it out, and to then take Maggie on the walk. Maggie's intention was to facilitate space for reflections on border places and spaces, as well as advance innovations in walking/biographical methods (using a sociological imagination) by listening to, and experiencing and reflecting with her co-walkers on the experience of the walk.

Our walk was inherently political and also deeply personal, with commonalities around social class identities, experiences of alienation and belonging, the importance in both of our biographies of education and a strong desire to challenge racial, sexual and social inequalities, 
as well as advance knowledge and understanding of migration and the social harms perpetrated globally against those on the move. It became apparent when walking and talking, but also afterwards and when reading the transcript, that the walk enabled us to do what Stuart Hall (1979) calls conjunctural analysis.

We are living through, in Stuart Hall's term, a particular conjuncture in Europe and indeed across the globe. Conjunctural analysis articulates a method introduced by Stuart Hall (1979) that focuses upon culture, ideology, language and the symbolic, using Gramsci's (as cited in Hall, 1979) articulation of the conjuncture: the "historical specificity" of a given time or moment. We utilize "the productive metaphor of hegemony" (Hall, 1996, p. 267) and 'conjuncture' to enable us to unpack a political moment. Hall defines conjuncture using Gramsci's 'hegemonic' understanding of power as the way popular consent is won, not just the way in which we are dominated by a system. Conjuncture is a framing device for trying to unpack a political moment. For example, in the context of the UK exit from the European project, how are racial others constructed in British society?

As Grayson and Little (2017) state: "Understanding the social, cultural and political forces that constitute a given historical moment" (p. 62) was crucial for Gramsci. Moreover, "thinking conjecturally allows us to historicise the present; and it is through our analysis of the present in all its complexity that we may be able to see the opportunity to take steps towards a new way of organising society" (Grayson \& Little, 2017, p. 63). Grayson and Little (2017) provide an example:

To indicate a few of those contradictions in neoliberalism: the production of competitive 'winner takes all' subjectivities that figure most people as losers; the fuelling of consumption by debt rather than redistribution while moralising about living within our means; and the failure to efface cultural differences in favour of rational choice while deploying rhetorics of diversity and equality. (p.74)

A good example of conjunctural analysis is the critical journalism of one of the authors, Ismail Einashe. In a recent talk on migration 'routes and roots', he starts by examining the migration journeys to Europe, stating that up to June 2018, 33,697 people have risked their lives reaching Europe by sea and more than 2,000 have drowned. Einashe informs the audience that failed asylum seekers cannot return to their home countries for fear of persecution, and so they live their lives in the shadows. Families are separated due to the minimum income rules introduced by the Conservative government in the UK and, indeed, the cost of family unification. Einashe underscores the racism underpinning the 'refugee crisis' and asks, 'why does nobody care when black African migrants drown?' And, of course, this is further evidenced by the longer trajectory and instantiation of a 'hostile environment' introduced in 2011 by Theresa May, the then Home secretary, that makes millions of Britons second-class citizens, especially those of the Windrush generation. ${ }^{i}$

Socially, culturally and politically, we argue that there is a need for conjunctural analysis that is biographical, theoretical, and looks at the relationship between history, structure and culture, to identify the new forms of neoliberalism, the shifting history and contexts of states' (and international community) responses to people on the move: from the age of border adjustments, the age of the camps, to the age of borders and walls to keep migrants out (O’Neill, 2010; O’Neill, Erel, Kaptani, \& Reynolds, 2019).

The authors, like Stuart Hall, are politically committed to the importance of ethnographic and participatory biographical research for conducting conjunctural analysis as a critical research practice, to open, and keep open, a space for a radical democratic imaginary and future, underpinned by social justice (Einashe, 2018; O’Neill, 2008). It may appear utopian 
but documenting and analysing the particular history of the present, through walking and biographical research as conjunctural analysis, will facilitate better knowledge and understanding, and potentially transformative possibilities for social change. Analysing the rupture of the present moment by deep biographical social and cultural analysis on the move also includes recognition that may lead to action and interventions towards a social justice that is "beyond white man's justice" (Hudson, 2006, p. 29).

\section{Conjunctural Analysis through Walking as a Biographical Method}

Biographical research methods provide a useful interpretive methodological approach to identify and evidence the present conjuncture. Biographical research seeks to investigate individuals' daily life experiences, and their past and future perspectives, using a variety of materials and interpretive approaches (Roberts, 2002). Fellow biographical scholars identify a 'biographical or narrative turn' (Bornat, Chamberlayne, \& Wengraff, 2000; Roberts, 2002) around the late 1970s and early 1980s, associated with the (re)emergence of "micro social theories" (Roberts, 2006, p. 134-135).

Theoretically and conceptually, the life history method came of age and was central to the work of the Chicago School—notably through texts such as The Polish Peasant in Europe and America by W. I. Thomas and Florian Znaniecki, and The Jack Roller by C. R. Shaw. A central focus was upon the centrality of meaning and sense-making, and stories as "symbolic interactions" (Fischer, 2011, np). Fischer (2011) reminds us that telling stories, as part of how we share and make sense of our social worlds, is part of human understanding and indeed is a "basic cultural competence" (np). Key figures in biographical and narrative methods suggest we lead 'storied lives', and that stories are also a ubiquitous feature of the cultural landscape (Jackson, 2010).

In the next section, we illustrate how stories do their work by sharing a biographical walk in central London that enables us to reflect on the problems of biography, history, and their intersections within social structures (Mills, 1959/2000), and produce conjunctural analysis. As Stevi Jackson (2010) reminds us:

The narrated and narratable self is temporally and socially located. The stories each of us tells about ourselves typically invoke a past (distant or recent), implicitly or explicitly linked to a present and perhaps to a possible future. The act of telling a story takes place within the flow of time and is situated within a sequence of social interactions between narrator and audience. Both the narration and the events recounted, position the teller in a social landscape. (p. 123)

Biographies help us to understand the processes, structures and lived experiences of people, of citizenship and lack of citizenship, partial citizenship, the multi locality, and personal and emotional forms of representation. As Shantz (2009) states, "biographical sociology holds the promise of a revitalisation of the sociological imagination at a time when neo-functionalism and objectivism would seek to restore the authority of the sociologist as expert" (p. 13). For us, walking biographical methods open up sociology as a public practice; and as a politics of articulation and representation informed by a politics of subalternity. Walking activates biographical sociology in a different way: with rhythm, pace, connection to the environment and landscape with nature, the weather, and in and through time, real-time and phenomenological time. Walking as biographical sociology (as we have both argued) can also facilitate alternative narratives and practices that may shift and challenge the dominant power/knowledge axis embedded in the governance of, and hostile environment for, asylum seekers and migrants. 
As this special edition and the work of Springgay and Truman articulate in the introduction to this issue it is imperative that current activations of walking methods take into consideration race, gender, sexuality, disability, and settler colonization (editors introduction this journal) and that "walking-with is explicit about political positions and situated knowledges" (Springgay \& Truman, 2018, p. 11). In the section below we document and analyse a particular conjuncture through a walking biography led by Ismail Einashe, who took Maggie on a walk that was important to him in Kentish Town and Camden, London.

\section{Walking with Ismail}

Our walk began outside Kentish Town tube station, which is where Ismail grew up. Ismail said that the walk would take us to the:

Citizens Advice Bureau, which is no longer there; that was a really important part of me growing up, when I think about it, because I was there all the time because we had lots of problems with family and stuff and I used to queue up there every other day. Kind of embarrassing; you'd see kids slightly better off, like, outside, and they'd ask me what are you doing here? And I'm like, 'oh, I'm here with my mum because they can't get benefits you know or whatever.' So, we'll go there and then maybe walk past a couple of shops and then I think we'll go down towards Queen's Crescent Market, which should be quite busy today and it's quite near the estate I grew up in.

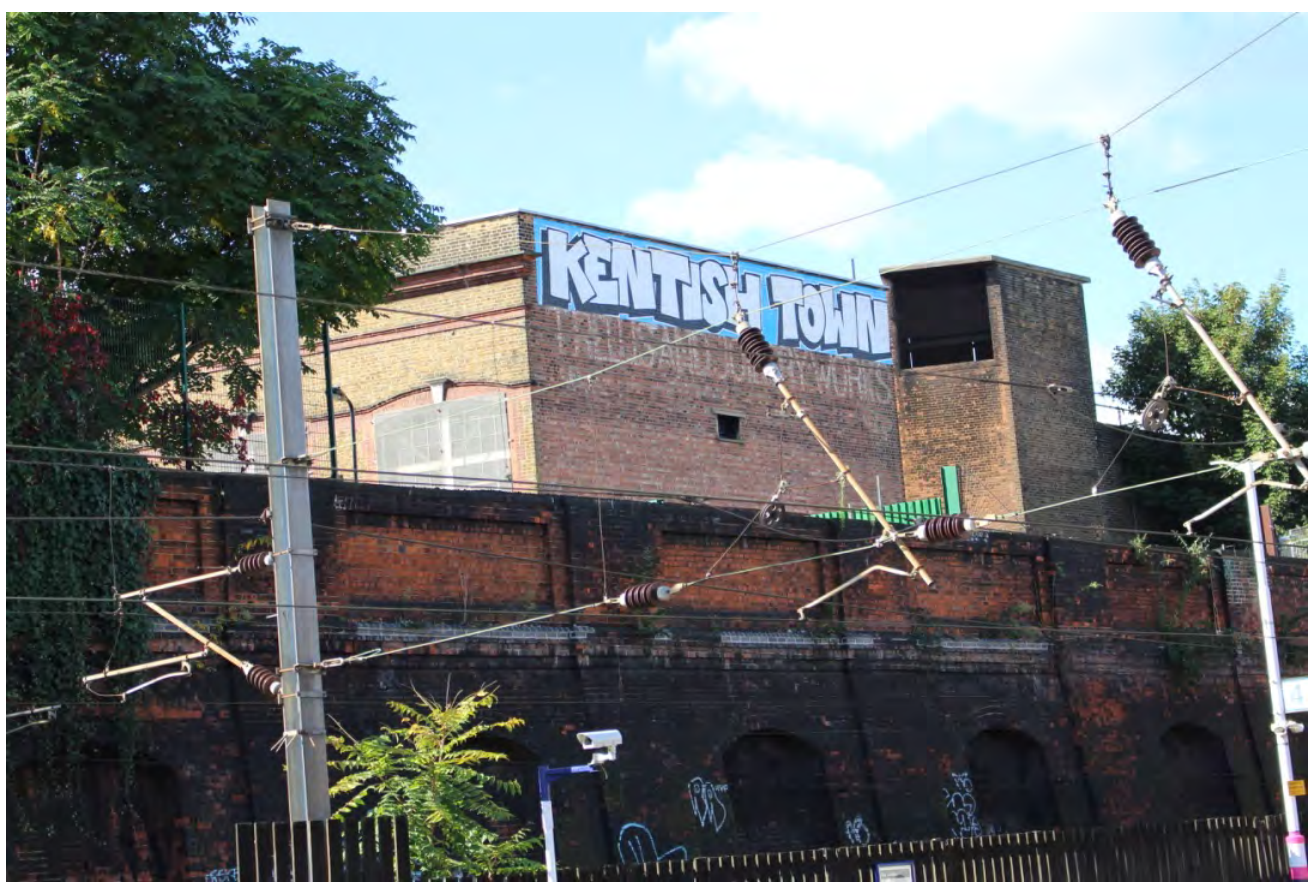

Figure 1: Kentish Town. Photo Credit: Author (Maggie).

I will take you through Camden and we'll go to lots of spots that are really important in my childhood and some of that will be quite intense. If we have enough time, we might stop by my former Sixth Form, Camden School for Girls [laughs - the Sixth Form is mixed-sex] and then we will go down the Camden road towards King's Cross and go past my secondary school I went until I was 16. 


\section{Early Life}

I moved to Kentish Town in 1997, so it's been over twenty years since I moved to Kentish Town now. And I came to the UK in 1994, just before Christmas with my family. I went on my first plane ride from Addis Ababa to Frankfurt and then came to London Heathrow. Within a week or so we were taken to this hotel on Camden Road, not far from here.

Standing on Kentish Town high street, Ismail reflected on the extent of movement in his early life:

It's a lot of this moving, a lot of movement, a lot of crossing boundaries and borders. It was all just a lot of change. I was born in Somalia but the war happened; we went to a refugee camp, came back to Somalia again, and then the war began again, so we went back and forth, and then went to Ethiopia, before arriving in London.

The first ten years were full of movement and trauma.

\section{Kentish Town community and history in the present}

Walking down the high street, Ismail spoke of how it was when he first arrived; a large Irish community was very present, "full of people and diversity. The Irish centre, Auntie Annie's, The Magpie, O'Reilly's — these were all the pubs on the High Street when we came here twenty years ago."

Gentrification and regeneration had led to the development of a solid middle-class reputation.

It's a bit intense, this area, for me; it became a kind of prison for me for a long time. I moved out when I was eighteen because I wanted to go to college and at that time it was 2003. I moved back, obviously when I graduated that's and then I basically moved away for three years to live with a friend in Chelsea and then I moved back here maybe when I was about twenty-two and then I stayed here until about twenty-six.

At this time, Ismail was working for a Member of Parliament and stood as a local election candidate.

Our first stop was the library.

Yes, so basically this is Kentish Town Library. This place probably changed my life because, as a child, I used to come here every Saturday. I used to go to Greggs bakers across the road. I used to buy yum-yums and doughnuts and then I used to come here.

We're going to stop at this guy here because this is the fruit and vegetable market here. It's really interesting because he was our neighbour in Barnet where we lived for a few years after arriving in London.

And they're a Kosovan refugee family and they were the people we met in 1995: yes, 1995, when we moved to Collingdale in Barnet near to this estate called Grahame Park and that family were from Kosovo and, like us, were refugees, and then many years passed, you know. I think we moved out first and then many years later I saw them here in Kentish Town and the father and the mother still work here.

Not much has changed really in this bit of the High Street. I mean, Iceland's still there! Macdonald's was always there. This Café Renoir has always been here and that pub over there used to be called O'Reilly's; it was an Irish Pub and this area was really rich with an Irish community for a very long time and it no longer is, and now it's very trendy. 


\section{Citizens Advice Bureau}

People would go to Citizens Advice Bureau. They would come here, and go and get their advice on their housing issues and their benefit issues, anything really, and that is basically no longer possible for people, but this was the place I wanted to show you and people used to queue right outside it for a long time, and I used to come here several times a week. It was just, like, a part of growing up, basically, because this was where you go; it was like a one-stop shop for advice.

So, it's a kind of interesting place to come back to and to kind of think, wow, this place has really changed: it's a fancy wine shop, Oddbins, and it kind of also shows this area was always a social mix, you know, you had people who were middle class here, people who were working class, but what's changed in the last, like, few years is that effectively, the very wealthy people are taking over the High Street. I mean, like, all the shops that are here don't really serve working-class needs and it really says something about how things have changed.

\section{Pound stretcher}

Let's go inside Pound Stretcher [laughs]. This is where I worked. You see, I've got to take a picture. OK this is it, for a second. Oh God! I think, oh God, it's empty; there's nothing inside. OK I think this is as far as we're going in.

For Kentish Town, it's a very symbolic place, a place in this area where working-class people come to shop and, yes, I worked in Pound Stretcher maybe 2002 or 2003; it was just an after-school kind of job. It was very interesting because, actually, one of the women who worked there still works here, and I occasionally go in there and I see her. This place hasn't changed.

\section{The Spa}

One place that hasn't changed by the way, if you look across the road, is Rio's Relaxation Spa.

Walking towards Camden Town, Ismail said the area has become less mixed in terms of access to housing because working-class migrant families can no longer afford to live in this area.

At this point, Ismail says:

I have places that bring up strong memories and connections and very important moments in my life living round here that happen to be, you know, buildings or shops or restaurants or, you know, public places, but, you know, for me this street is where you had to go through to get to Camden Road, to get to my sixth form, and there's a little park there where the kids still go, but that's where you would get to go and play games and things. One such place is Adam's flat.

\section{Adam's flat}

My friend Adam moved here after university to this street and it became more interesting to me because Adam and I went to university together and his parents happened to own a flat in Kentish Town. I mean, they lived in like Kingston somewhere far away from here but that basically meant I was able to escape my family and come here and I was able to kind of get drunk [laughs] so actually, obviously, this is special for me because it was his flat. 


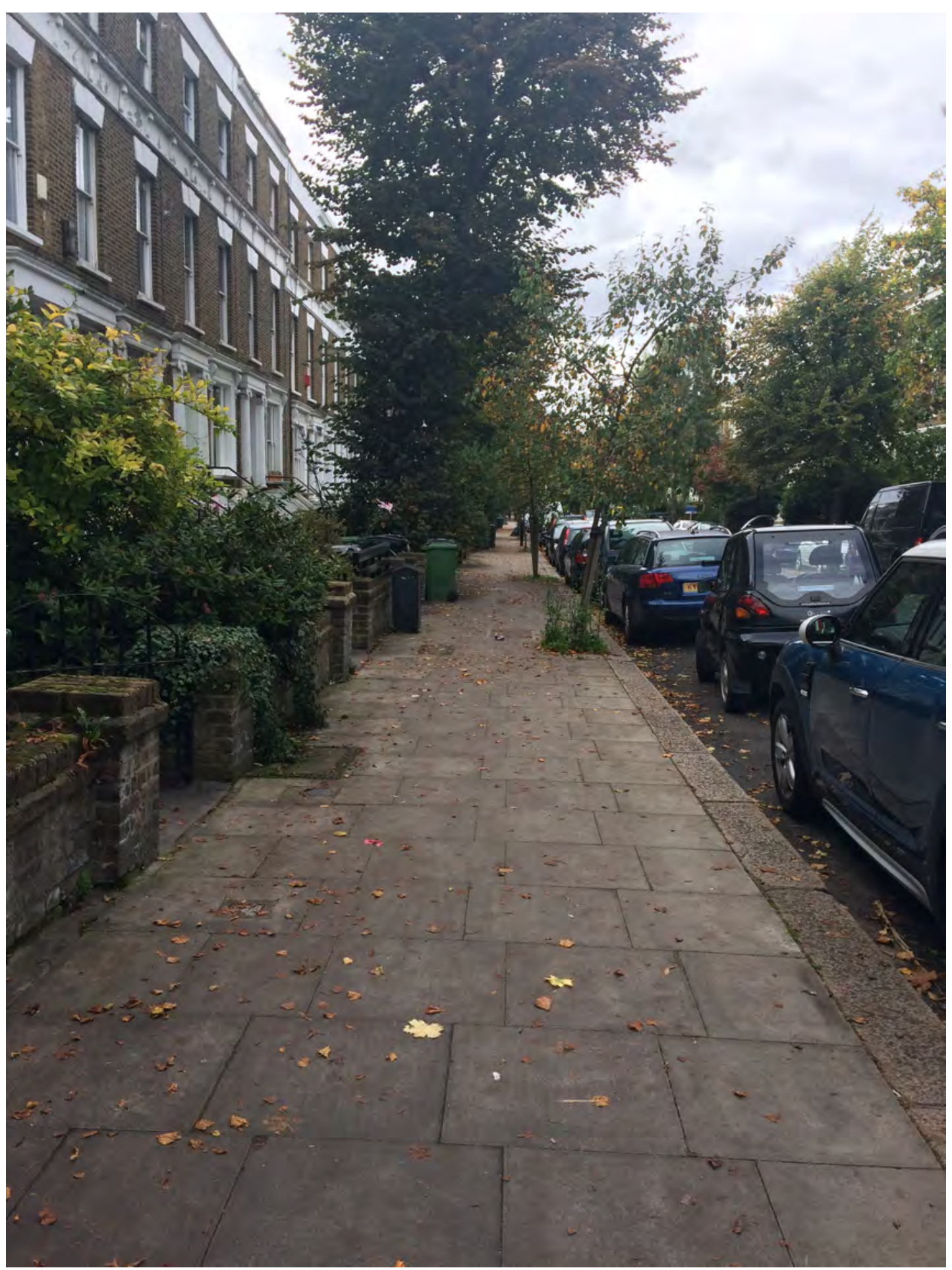

Figure 2: Adam's street. Photo Credit: Author (Ismail)

It was definitely a place of fun and lots of friends of ours from university also lived with him.

\section{Kentish Town Community Centre}

The Kentish Town Community Centre is really important, so this is where they organise events and meetings. I used to go there a lot, and this is where they have the Somali Youth Development Resource Centre, which a lot of my friends were involved with, but, yes, it's 
a really important community space. I haven't been for a really long time, but I know that my cousins and other young people in my family do go and play, like, Saturday sports and stuff in there.

So, within this space, there are still these community spaces where people come together, where people figure out what's going on; but generally speaking, there's been lots of cutbacks to youth funding. There used to be a youth centre right next to where I grew up, but I don't think it's there anymore.

Ismail pointed out the border between Kentish Town and Camden.

Right, OK, so we've just now basically left the boundary between Kentish Town and Camden, so I guess this area is really Camden. It's the Camden Road area going north towards Holloway.

Let's cross here and we are now going to the first official residence where I ever lived in the UK and this was a hostel/ hotel I guess; it felt more like a hostel because you were given rooms, but you weren't given any food. I think there was milk they used to bring us but you would cook in these communal kitchens.

\section{Corner House Hotel}

I think it is this one, let's turn around and see it, and it was a really interesting period; it was in 1995 and this place was home to Kosovans, Bosnians, Kurds, Somalis: people who had fled conflict zones and who were arriving in the UK. They came as asylum seekers and they were basically put in these places, and I think I must have spent several months here. I don't remember going to school at the time. My mum didn't let me go outside to play because she was really scared of what was outside those Victorian brick walls, so I just used to observe everything from just one of these windows, maybe on the fourth floor of the building, I'm not exactly sure. But here we go; oh, it's the Corner House Hotel.

I remember feeling suffocated in there and I didn't speak English. It was really difficult. I didn't understand much, and I think the only happy memory I have is this: an Albanian couple that used to always smile at me and once I accidentally saw their door open and saw them in bed. I was a child I had no idea what they were doing, I just stood there smiling at them (of course now I know what they were up to [laughter]). Anyway the woman was startled and the next day her husband bought me like a box of Quality Street chocolates [further laughter]. Anyway, I was like ten, I wasn't sure what was going on.

So, we are now on the Camden Road and the traffic is really heavy and it's always been a really busy road and this road for me also has very intense memories because if you go north of here then you end up in Holloway Road, and then Finsbury Park and Finsbury Park is where I went to mosque.

At this point, Ismail spotted the 29 Bus.

I would get that bus, the 29 , which is right there. Let's cross here. Oh, and that was such a tortuous bus: I hated that. I was forced by my mum to go on these enormous shopping journeys and it would always be on that bus.

It was really awful because it was always like this weird thing of, I would get off the bus there and then get on the bus and it was just annoying because I had to carry all these big shopping bags and we'd go to miles away to this store Netto, which is where you would get cheap food. 
And because we were on a budget and were on social benefits, it was really difficult you know, so we'd have to carry these bags to survive; there was no money for taxis so it was like, aged twelve, fourteen, fifteen years old, whatever it was, always something that you had to do. It was always horrendous and awful, and I just hated it. Yes, so that is a memory I have of carrying those heavy shopping bags full of, like, lamb meat and other such delights.

So, we would go every Friday, Saturday and Sunday to Finsbury Park neighbourhood to the Finsbury Park Mosque and then at other times you know I'd make that journey four or five times a week on that bus! And it would always involve having to go shopping and, when you went shopping, you'd go to somewhere like Turnpike Lane area even further north of Finsbury Park because they had good halal butchers was what the mums said on my housing estate. So you'd go all the way there for these collections of Halal butchers; you would get your meat: kidneys, liver and all that stuff and then you'd go to Netto for all the cheap stuff like pasta, rice, bread, pulses, beans, eggs basically. Actually, back then I mean it was very difficult to find specialist food to make lamb curry or special rice, so that was the only place that we could go and get like the spices that you needed, to get tamarind, but now, of course, you can buy tamarind in the supermarket, but back then they didn't even have turmeric or cinnamon in the supermarkets. But up in Finsbury Park and Turnpike Lane there was a Turkish/Kurdish community, so they had all the things that we used and also, I took that bus a lot during Ramadan, because you'd go to Ramadan prayers in the evening.

\section{Camden School for Girls}

So, we are here at Camden School for Girls. They take boys in the Sixth Form but the lower school is for girls only. Still, in the Sixth Form, maybe it was 30\% boys and $70 \%$ girls.

Now, when I look back on it, I think it was a really good school; it's a mixed Sixth Form, but the difference is it's a state school. It was founded by Mary Buss, a campaigner in the nineteenth century, a pioneer for female education. And I came from the terrible local state school. It was the first time I ever knew what middle-class was. It was the first time I really had any white friends because the school I went to before was 90 per cent non-white and it was a very different sort of school here, the kids dressed differently, they spoke differently. It was the first time that I was aware that I was different: that I was not just different because of the colour of my skin, but different because of my class, and there were certain things that I wasn't ever going to be good at or get or understand.

I'm still friends with people I met at this school. I went there for two years so you know I was aware of being different and I remember one girl just saying something about this popular boy who I actually saw last night—my friend Matt. He was really popular, a really handsome boy and the girls loved him, but this girl said when Matt and me became friends, 'I can't believe Matt's hanging out with Ismail, he's from a lower social class.'

\section{Social class}

So, I was really aware of that and I remember, when I worked at Pound Stretcher, I remember the kids all thought it was really hilarious because none of them had to have a part-time job when they were sixteen. I did, but I used to bring them badges from Pound Stretcher as a kind of joke you know, but basically, I learned a lot. I feel like if I hadn't gone to Camden School for Girls it wouldn't have prepared me to be able to survive in middle class, white society, that's a fact. Because it taught me things that I wouldn't have known, had I not gone there, because it exposed me to this whole other world that was just round the corner, but I never knew existed. 
At that point, I felt like the middle classes were important until I actually went to Cambridge University and met normal middle-class people from the rest of the country and I realised I had effectively, lived amongst London's liberal metropolitan elite.

I was also very active in that school, you know, and I think, in a way, like becoming aware of middle-class lifestyle and the world around here, made me become more insecure, because there's so many more things to be worried about.

So, I think for me, I spent so much time observing their lives and them, and going to their houses and being friends with their kids. I remember people used to say 'oh, the journey from Somalia, what was that like'? And I just think you know, and I'm also very critical of these types of people because I think they actually live next to danger and/or really extremely poor people, but actually they defend their privilege to themselves, you know.

Also, like class, it was the first that I was aware when I got into Camden School for Girls of being not even just working class but being a migrant or refugee and Somali. Somalis have a particularly distinct culture and a distinct look so we're very visible and you know we're just Somalis. There was no black kids really at Camden School for Girls Sixth Form, because to get into that Sixth Form, by the way, you need 5 As to Bs of GSCEs exam results.

I managed to get into Sixth Form but my teacher at my old school said you have to leave and go to Camden School for Girls for Sixth Form if you want to go to a good university so that's what I did.

I was becoming aware of this class consciousness rising within me and I felt like I was always sort of confident and bubbly and happy and I used to talk to everybody. I had no real issues, there was no real difference for me between this group and the other group and then gradually I became very aware that within halfway through the first year of this school I had no real friends, and then I eventually became friends with a group of people who had all basically gone to the same school. They'd gone to City of London boys and girls, which is one of the biggest private schools in London, and I'm still friends with them; I was with some of them last night.

It was a really disorientating experience. I didn't really realise that was normal for middle classes that probably take one holiday a year if they're lucky, or two holidays maybe, and maybe go to Spain or somewhere. People round here, they would go to the Dordogne and Nice and Italy and they're going somewhere else and you know it's kind of a lifestyle.

\section{Job Centre}

This was always a terrible, frustrating place and I hated this place, let's get out of here as quickly as possible. It was because this is where we'd come to argue about why benefits had been cut with my mum, and you had to fill out forms and when I was unemployed I had to go and fill out forms. There was a period when I was not working and I had to come here and it was always just, there's an element of depression and kind of yuck, you know.

\section{Kentish Town Public Baths}

This place, I spent a lot of my youth here swimming. Actually, if you asked me about a special place this was probably the happiest place.

It was also really tricky because I had to sidestep these boundaries and borders and you know it was really difficult because I was a young person it was the first time that I left that school and gone somewhere very different and my friend's parents were very different to the people that I was around. Of course, I began to drink alcohol and my family would see me and they would complain and there was like all these cultural territories that I was over-stepping 
and I wasn't going to the mosque and I was becoming visibly less religious and you know, I used to hide from my family in pubs. Every pub here is a kind of trauma.

Because the kids all went to pubs locally and they'd go 'oh look your cousin's coming, hide' or 'someone Somali's coming,' so I became terrified of anybody who was basically Somali after the pub because I'd get into trouble you know and I used to go and spray lots of Lynx before I went home to make sure they couldn't smell the alcohol.

\section{Trauma}

So, you know I grew up in a community of Somalis around here and they basically have profound trauma and we have serious levels of mental health issues. Where I grew up, which is the block just from here, is one of the most deprived areas in London you know, extreme poverty next to extreme wealth.

I should show you some of the Somali shops. When Somalis moved in round here, in like in the mid-1990s, there weren't that many shops but now it's changed. This was a hostile area when we first moved in here because I think they moved Somalis and people like us into certain blocks. This was still where white people lived here and I think there's a lot more integration but back then it definitely wasn't very integrated.

There was a lot of violence, so the kids used to run up and down here, and there were people selling drugs underneath that railway arch. I mean look at those two, I'm sure that's what's going on and especially underneath here would be where the drugs would be sold. I mean this was a very dangerous area in the 90s and now we are walking back towards Kentish Town High Street and we're going to walk towards Camden across a canal.

\section{Somali community}

So, this is basically exactly the same shops, cash converters is what we call it because it's cheap and also this is where people come to pawn everything and also cash cheques. The coin-op laundry - we used to come and do our washing here. So, that's my barber's shop, well it used to be my barber's shop.

Ismail pointed out the bike shop and the last remaining family Irish pub.

This is the bike shop: I bought my first bike here. This is the last remaining family Irish run pub because they have all closed down. This area was really active you know Kentish Town/Camden this whole neighbourhood was totally Irish for a very, very, very long time, and it basically changed and it's where you could get a drink on Christmas Eve. It was the only place open so-because all my friends would, you know, come back to Kentish Town-we would all come here, you know.

\section{Camden High St}

There are tens of thousands people that come here; to be honest, I'm not really sure why because it's kind of terrible, but so this is this spot; awful.

This is where a Radio 4 programme that I made did starts, it's this spot by Camden Town Tube station: it's where my childhood friend Mahir was killed. 


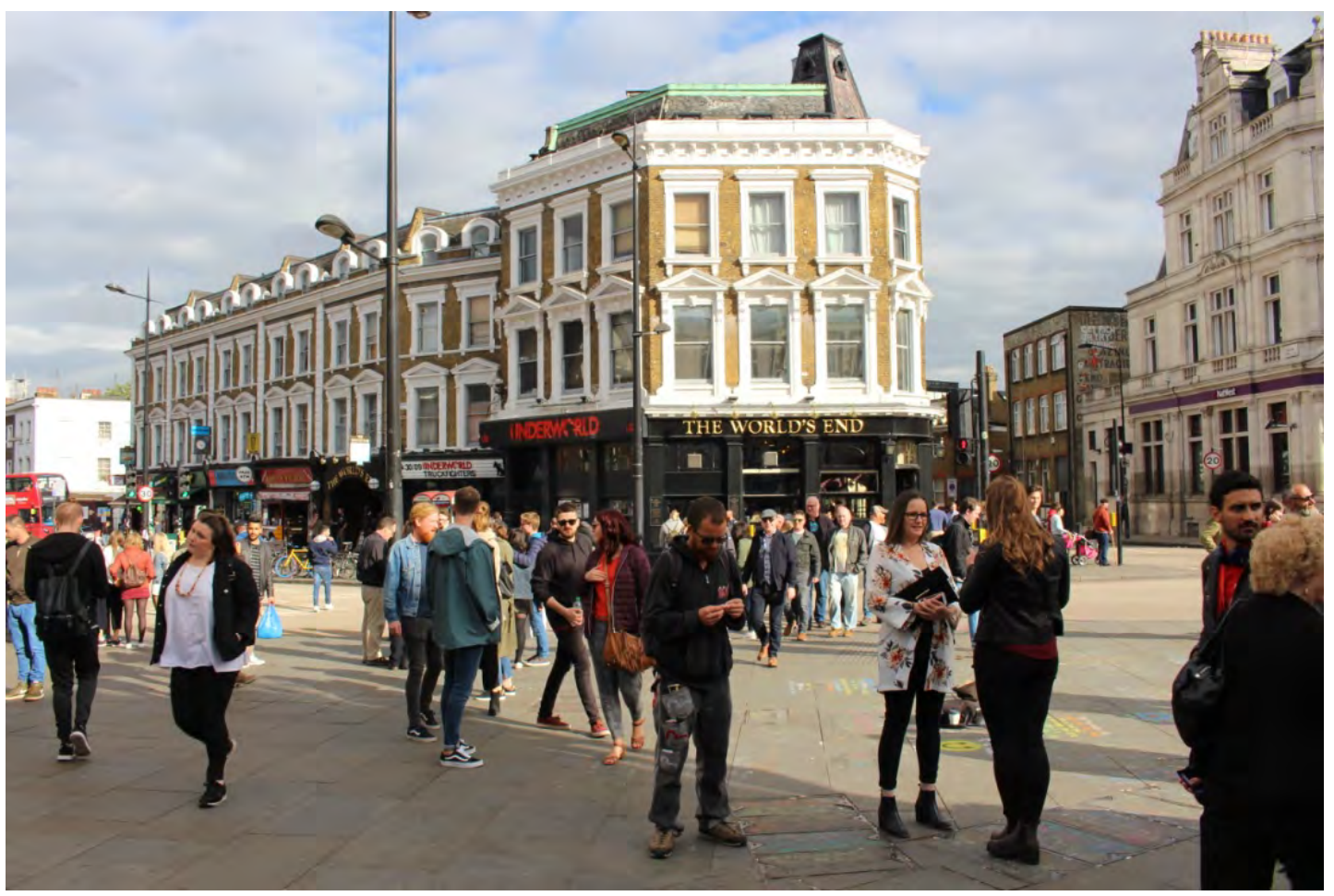

Figure 3: Camden Town. Photo Credit: (Ismail).

\section{Mahir}

In 2006, it was a January night, it was very cold and he got off the 29 Bus, I think over there, and he was chased by a group of boys, maybe fifteen or more, stabbed to death and died. I mean that was really the most shocking manifestation of all the growing up around gang stuff. You will see boys hanging out, people selling weed or whatever and at this spot, this is where you would see people selling weed and kind of harder drugs, and eventually it became like more intense you know, but this was a zone that was dangerous and most of the people who were tourists were oblivious, but there are invisible boundaries. It's like, you know, adults didn't know, but there's certain areas you couldn't walk to because it's also like a contested territory between Jamaican and Somali boys and if Jamaican boys saw a Somali guy they would beat you up, there were lots of cases of that and then vice versa, so there are all these kind of invisible boundaries and borders that you know you couldn't cross and you wouldn't cross. Let's walk.

\section{Mosque}

I had to go through all of that noise and business to get to here, because this is where we went to Somali Madrassa, to religious school. Until I was going to Finsbury Park Mosque I used to come here.

Ismail pointed out an anonymous police house.

Here is basically an anonymous police house but this is also one of the spots where the boys would be and the gangs would be and it was all around here and there'd be people running up and down here, arrests made, you know. Camden in those days was quite dangerous.

And again, look, I didn't notice this, there's another police, anonymous police house. It's next to a Bangladeshi butcher. 


\section{Caravan site}

The Irish are very dominant around here. Where we were on Camden Road was where the London Irish Centre was, but the whole area really has that history of the Irish. Later on, the Greeks and Turks came, but now the Greeks and Irish have moved on or the ones that haven't are still in their council houses, but they've done all right and became middle class and they moved away somewhere else, but they still come back. There was a big Greek community. We'll walk past a few Greek restaurants on the other side.

\section{Greek community}

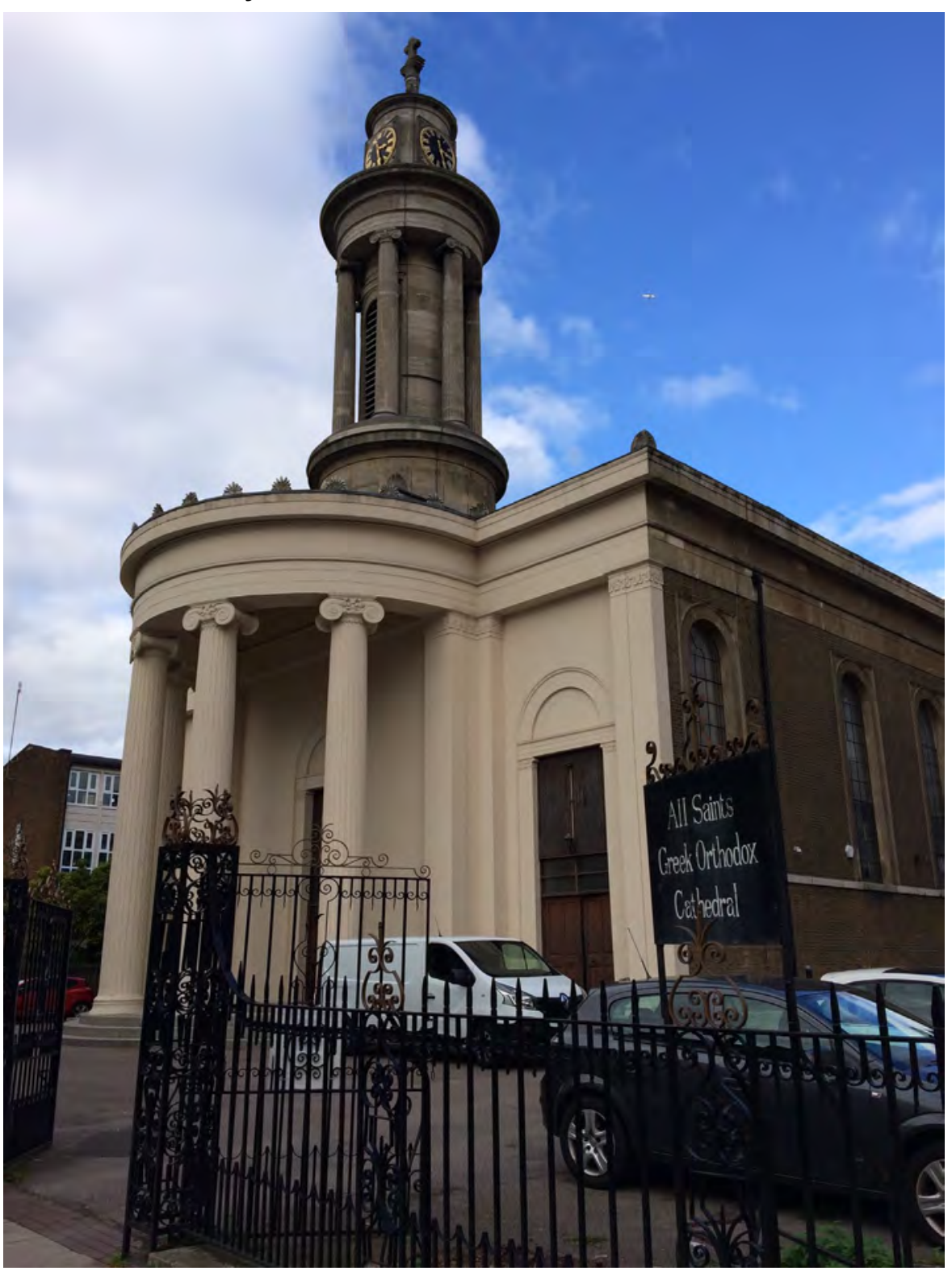

Figure 4: Greek Orthodox Cathedral. Photo Credit: (Ismail).

Yes, and they have these amazing kind of weddings here, but yes that's All Saints Greek

Orthodox Cathedral; it's not a church, it's a cathedral. 


\section{Somers Town}

I would take that route every day to school from the age of twelve to sixteen, basically when I was Year 8 to Year 11. That's the longest I'd ever continuously studied in one place, at South Camden Community School, which no longer exists; it's now called the Regents High School. It used to actually be called Sir William Collins School for boys and then it became South Camden Community School and it became co-ed.

And in 1994, I think was it, a boy called Richard Everett was murdered outside the school. By a group of Bangladeshi boys and it was a racially motivated murder and the school became notorious. There was actually a lot of inter-ethnic violence. The majority were Bangladeshi, there was some Kurds, there were African kids, there was a lot of Turks, and the minority were the white kids there. I'd get hit so many times, I'd get into arguments and fights and we learned nothing, half of the school was taught by supply teachers, it was really bad.

I got the grades and I didn't really know much about Camden School for Girls, but I knew I wanted to get out, get out of South Camden.

It was amazing recently because, after I wrote an article in the Guardian newspaper, I got a letter, actually let me read it to you because it's so sweet and it was actually really appropriate because we're going to be coming up to this school. So, I got an email from Miss Hayes who taught me religious studies and history I think. I haven't seen her since 2001 and she was one of, not the closest teachers, but she definitely encouraged me a lot.

And this is what she said. She said:

Hi Dear Ismail it's Miss Hayes here, remember me from your school days. I was reading the Guardian Weekend Magazine this morning and your article caught my eye. I looked at the author and thought to myself that name seems familiar but I couldn't place it. I read the first few paragraphs and thought it must be a person from South Camden Community School and your face came to mind. I carried on reading and became more convinced that it was you, so of course I had to get onto the Internet and look up the name and there you were, a little older but your face is just the same. I was so happy and proud to see how well you have done in life so far. Your mum must feel so proud of you and what a role model you are for your brother and his peers. You went on to Camden School for Girls for the Sixth Form I recall and then on to Cambridge University. I shall look up more articles online that you have written and read them with extra interest. I have already emailed the article to Miss Hough, I'm sure you remember her too, she was as delighted as I was to know how well you have done in life, we often meet up as we are both still living in London. I intend to email your article also to Miss Hilali who's another teacher from South Camden that I keep in touch with. Very best wishes Ismail and once again, well done for persevering in what I know is not an easy environment for non-white working class males. You're a role model for young men in your community and beyond. Very best wishes, Miss Hayes.

Such a moving email. We were coming to the end of the walk.

Ismail says, "so, this is Somers Town and the end of our walk:"

Historic Somers Town is sandwiched between Euston and the back of King Cross, St Pancras and before Camden; it's that little bit of land which also goes up towards maybe Caledonian Road, but this is Somers Town.

They've invested a lot of money because the school was neglected after eighteen years of a Conservative Government that there was no investment ever and Labour Party came in 1997 and this became a Foundation or Business or whatever school, but it was too late for 
me. So, this gate here, there used to be a gate there, that's where Richard Everett was murdered in 1994.

\section{Conclusion}

Ismail ended our walk on the violence endured, the bullying and hitting in school and the fear involved in travelling home along these streets for his younger self. Maggie thanked Ismail for sharing his walk on borders, risk and belonging, and for the memories he had shared as well as his history told in relation to time and the places, buildings and landmarks of the walk, as well as the significant people he talked about along the way.

We discussed the way that life stories, biographies, are created over time and connect to places, and that our cultural identities are formed in relation to these histories, people and places. As Hall (1994) argued in Cultural Identity and Diaspora, cultural identities are not:

eternally fixed in some essentialised past, they are subject to the continuous 'play' of history, culture and power. Far from being grounded in a mere 'recovery' of the past, which is waiting to be found, and which, when found, will secure our sense of ourselves into eternity, identities are the names we give to the different ways we are positioned by, and position ourselves within, the narratives of the past. (p. 225)

What was apparent in Ismail's biographical walk was an articulation and understanding of the ways that "black people, black experiences" are "positioned by, and position ourselves": that "we can properly understand the traumatic character of 'the colonial experience" that includes the exercise of power, "dominant regimes of representation" that present as 'normal' although they are in fact hegemonic (Hall, 1994, p. 225).

Hall goes on to say that:

Not only, in Said's 'Orientalist' sense, were we constructed as different and other within the categories of knowledge of the West by those regimes. They had the power to make us see and experience ourselves as 'Other'. (1994, p. 225)

Developing this analysis further, we feel it is important to challenge the dominant regimes of understanding and identify the particular conjunctures that are involved in racism, and othering, that Ismail himself has experienced, including the architecture of law and power. Ismail later writes in an article in Frieze magazine that responding to the crisis in the Mediterranean also means understanding the "Eurocentric architecture of legal definitions" (Einashe, 2018, para. 5). This would include decolonizing the 1951 Refugee Convention for:

it is too limited to respond adequately to the contemporary scale of migration that has been caused not just by war but [also] by climate change and economic crises. If, say, a Gambian or Senegalese migrant journeys to Europe in search of a better life, they are not perceived to be as deserving of the same level of sympathy as a Syrian. The result is a league table of migrant suffering and the reiteration of simplistic binaries between good versus bad migrants. (Einashe, 2018, para. 5)

This is a Dickensian way of "understanding the complexities of what motivates people to leave their homelands" (Einashe, 2018, para. 5). He goes on to say:

To illegally cross a border, to evade border guards, to scale metal fences and survive the Mediterranean Sea is an act not only of survival but of the imagination. To end this tide of human misery not only requires sensible, humane and unified government policies, but a willingness to understand the deeper histories of colonialism and violence that render nonwhite bodies as victims lacking agency. The current situation renders Africans invisible and, 
for many Europeans, Africa itself is simply reinforced as a caricature of its nightmares and beauty. (Einashe, 2018, para. 6)

The actuality of conjunctural analysis is articulated in the following quotation by Ismail on our walk. In the sharing of biography, memories and, indeed, in working through the past, Ismail highlights the following:

Europe's borders are rooted in slavery, colonialism, mass extraction and global capitalisma plethora of historic political forces that have imbued the west for centuries with power and wealth, at the expense of countries in the global south. When it comes to current public discussions about immigration in the Mediterranean and beyond, this is a fact that is rarely acknowledged. Decolonizing means the creation of a decolonial gaze in order to understand the historic context of migration, yet, going by most news reports, this has not happened.

The walking interview, as a biographical method, is an example of walking as critical pedagogy that elicits conjunctural analysis, in the moment and on the move. In her earlier work, Maggie discusses walking as an ethno-mimetic method, and the creative application of walking in biographical research "as a deeply engaged relational way of attuning to the life of another that evokes knowing and understanding," for when "walking with another we can engage in an embodied and corporeal way and attune to the narratives and lived experiences of research participants" (O'Neill, 2015, p.74).

Taking a walk with Ismail on borders, risk and belonging opened a space for dialogue and communication in reciprocal ways in that the "physical and embodied process of walking, remembering, sensing-attuning-is constitutive and the relational shared process opens up a discursive space that can also be a reflective space" (O’Neill, 2015, p. 76). Walking is an embodied research practice and process that is relational, discursive and reflective. Importantly, it is also sensory and multi-modal in that multiple modalities of experience can be shared. Such methods constitute what Back and Puwar (2012) term live methods, "creative, public and novel modes of doing imaginative and critical sociological research" (p. 6).

Our argument here is that walking is a method for undertaking conjunctural analysis as well as biographical research, engaging the senses, meaning-making and opening the possibilities for resonance (Rosa, 2019), for connecting with co-walkers/each other in a way that evokes sensory perception, meaning and understanding (in non-procedural ways).

As we finalised this paper, we both agreed that re-reading the transcripts and organising the text and images was an emotional experience. ${ }^{\text {ii }}$ Ismail said that, in re-connecting with memories, and reflecting on borders and his own journey and the people left behind, "there's always a risk in walking borders some get left behind." At the end of the walk Maggie said: "I feel very close to you as a consequence of the walk and with the places you took me to. This has left an imprint/mark/resonance on me that I will feel when I am in those places in the future."

We both reflected on the importance of memory and methodology in migration research, the usefulness of walking together in creating a space for dialogue, resonance, understanding and the importance of highlighting the 'feeling' dimension of social research, as well as the critical conjunctural analysis; not least for the potential impact on hearts and minds, which ultimately is what Ismail seeks to achieve through his critical journalism and Maggie through her participatory arts-based research. Walking can create space for stories of asylum, migration and marginalisation to be shared and heard through critical pedagogy, as an artsbased research method-towards a radical democratic imaginary (the opening and keeping 
open of a space for critical and imaginative thinking beyond hegemonic thinking, that enables the repressed elements of the imaginary to be articulated) facilitated by conjunctural analysis gained through walking with another, through biography, place and time.

There are of course challenges for this kind of research. The subject-subject relationship we elicited through mutual reciprocity and Ismail's situational authority in guiding Maggie around his Camden and Kentish Town could so easily become interpreted and actioned in a procedural and instrumental — rather than organic — way, foreclosing the very possibility of a subject-subject mutual relationship. In the process of the walk, we did not follow a research 'procedure' or 'technique' but rather Maggie invited Ismail to share his walk and the stories connected to the places he would take her, and as far as possible actively listened and exchanged her experiences where there were commonalities. Social class, race and migration, understanding, and the particular conjuncture through time, place and subjective experience and memory was elicited through walking. We experienced this as a powerful way of doing critical analysis, of understanding and experiencing the global in the local, that engages in unsettling and troubling the white male privilege and basis of walking, and indeed the 'turn' to walking rooted in Eurocentric practices; for the history of walking in literature is a history of men who walk, white men, artists and visionaries. Walking with Ismail troubles this andlike the work of Springgay and Truman (2018) and the papers in this special edition-highlights the critical pedagogic possibilities of walking, as well as the meeting with another, attuning and engaging in their routes and lived experiences in ways that honour those experiences and open a space for de-colonizing research methods, processes and practices.

\section{References}

Back, L., \& Puwar, N. (2012). A manifesto for live methods: Provocations and capacities. The Sociological Review, 60(1), 6-17. https://doi.org/10.1111/j.1467954X.2012.02114.X

Bornat, J., Chamberlayne, P., \& Wengraff, T. (2000). The turn to biographical methods in social science. London, UK: Routledge.

Einashe, I. (2018). Reading the 'Black Mediterranean' through Europe's migrant crisis. Frieze. Retrieved July 23, 2019, from https://frieze.com/article/reading-blackmediterranean-through-europes-migrant-crisis

Fischer, W. (2011). Biographical reconstruction as applied knowledge or professional competence? Paper presented at the mid-term conference of the Biographical Perspectives on European Societies, Research Network 03 of the European Sociological Association, Nuremberg Germany.

Grayson, D., \& Little, B. (2017). Conjunctural analysis and the crisis of ideas. Soundings, 65, 59-75. Retrieved April 9, 2019, from https://www.lwbooks.co.uk/sites/default/files/s65 05grayson_little_0.pdf

Hall, S. (1979, January). The great moving right show. Marxism Today, 14-20. Retrieved July 23, 2019, from http://banmarchive.org.uk/collections/mt/pdf/79 01 hall.pdf

Hall, S. (1987, June). Gramsci and Us. Marxism Today, 16-21. Retrieved July 23, 2019, from http://www.banmarchive.org.uk/collections/mt/pdf/87 06 16.pdf 
Hall, S. (1994). Cultural identity and diaspora. In P. Williams \& L. Chrisman (Eds.), Colonial discourse and post-colonial theory: A reader (pp. 227-237). London, UK: Pearson Education Limited.

Hall. S. (1996). Cultural studies and its theoretical legacies. In D. Morely \& H.-K. Chen (Eds.), Critical dialogues in cultural studies (pp 262-275). London, UK: Routledge.

Hudson, B. (2006). Beyond white man's justice: race, gender and justice in late modernity. Theoretical Criminology, 10(1), 29-47. doi:10.1177/1362480606059981

Jackson, S. (2010). Self, time and narrative: Re-thinking the contribution of GH Mead. Life Writing, 7(2), 123-136. doi: 10.1080/14484520903445255

Mills, C. W. (1959/2000). The sociological imagination. Oxford, UK: Oxford University Press.

O’Neill, M. (2008) Transnational refugees: The transformative role of art? Forum Qualitative Sozialforschung / Forum: Qualitative Social Research, 9(2). http://dx.doi.org/10.17169/fqs-9.2.403

O’Neill, M. (2010). Asylum, migration and community. Bristol, UK: Policy Press.

O’Neill, M. (2015). Participatory biographies: Walking, sensing, belonging. In M. O’Neill, B. Roberts \& A. C. Sparkes (Eds.), Advances in biographical methods: Creative applications (pp. 73-89). London, UK: Routledge.

O’Neill, M., Erel, U., Kaptani, E., \& Reynolds, T. (2019). Borders, risk and belonging: Challenges for arts-based research in understanding the lives of women asylum seekers and migrants 'at the borders of humanity'. Crossings: Journal of Migration \& Culture, 10(1), 129-147. https://doi.org/10.1386/cjmc.10.1.129 1

O’Neill, M., \& Hubbard, P. (2010). Walking, sensing, belonging: Ethno-mimesis as performative praxis'. Visual Studies, 25(1), 46-58. doi:10.1080/14725861003606878

Roberts, B. (2002). Biographical research. Buckingham, UK: Open University Press.

Roberts, B. (2006). Micro social theory. Basingstoke, UK: Palgrave Macmillan.

Rosa, H. (2019). Resonance. Cambridge, UK: Polity Press.

Shantz, J. (2009). Biographical sociology: Struggles over an emergent sociological practice. a/b: Auto/Biography Studies, 24(1), 113-128. doi:10.1080/08989575.2009.10846791

Springgay, S., \& Truman, S.E. (2018) Walking methodologies in a more-than-human world: WalkingLab. London, UK: Routledge.

Ismail Einashe is a feature and investigative journalist. He has written for The Sunday Times, The Guardian, The New York Times, Prospect, The Atlantic, NPR and The Nation, among other places. He is a member of the editorial board of Tate Etc. the largest art magazine in the world. He has worked for BBC Radio Current Affairs and presented on BBC Radio. He has reported from over a dozen nations in Europe and Africa covering migration and refugee issues, citizenship and belonging to conflict and human rights in Africa. He is also a 2019 Alicia Patterson Foundation Fellow, an Ochberg Fellow at the Dart Center for Journalism and Trauma at Columbia University, and an associate at the Cambridge University Migration Research Network (CAMMIGRES). 
Maggie O’Neill is Professor in Sociology at University College Cork (former Chair in Sociology/Criminology at the University of York and in Criminology at the University of Durham) her inter-disciplinary research career has developed along a threefold path: the development of cultural, criminological and feminist theory; the development of innovative arts-based methodologies for doing social research, including walking, visual, ethnographic, participatory and biographical methodologies (ethno-mimesis); and the development of praxis (policy) as an outcome of scholarly activity.

\footnotetext{
${ }^{i}$ The Windrush generation are the people who were invited to migrate to the UK from the commonwealth countries Jamaica, Trinidad and Tobago and Barbados (the Caribbean) between 1948 and 1971. The name Windrush refers to the ship that brought the first people to the UK in 1948.

ii Maggie took photos at the start of the walk and Ismail took photographs along the walk, of the places he stopped at and talked about. Both took turns holding the microphone. The transcript was pretty much represented here verbatim and we hope the images really help the reader to connect to the walk and biographies.
} 